ISSN $0853-2788$

\title{
ISOLASI SIKLOKOMUNOL DARI DAUN SUKUN Artocarpus altilis (PARKINSON) FOSBERG SERTA AKTIVITASNYA SEBAGAI ANTIKANKER
}

\author{
SIKLOKOMUNOLISOLATION FROM BREADFRUIT LEAVES Artocarpus altilis \\ (PARKINSON) FOSBERGAND ITS ACTIVITY AS ANTICANCER AGENT
}

\author{
Chandra Risdian ${ }^{1)}$ Tjandwati Mozef ${ }^{(1)}$ dan Puspa D.N. Lotulung ${ }^{2)}$ \\ 1) Pusat Penelitian Kimia LIPI, Jl. Cisitu-Sangkuriang, Bandung 40135 \\ ${ }^{2)}$ Pusat Penelitian Kimia LIPI, Kawasan PUSPIPTEK, Serpong 15314 \\ Email: chandra.risdian@gmail.com \\ Diterima : 27 Juli 2014, Revisi : 05 Agustus 2014, Disetujui : 14 Agustus 2014
}

\begin{abstract}
ABSTRAK
Daun sukun (Artocarpus altilis) sudah lama dijadikan sebagai obat tradisional untuk mengatasi berbagai penyakit seperti liver cirrhosis, hipertensi, dan diabetes.Ekstrak etil asetat dari daun sukun juga berpotensi menghambat pertumbuhan sel kanker.Beberapa senyawa yang telah diketahui sebagai agen antikanker di dalam ekstrak etil asetat daun sukun adalah golongan geranil flavonoid.Akan tetapi, senyawa pyranoflavoid belum dilaporkan dapat ditemukan pada daun sukun.Untuk itu, penelitian ini bertujuan untuk mengisolasi senyawa pyranoflavonoid dari ekstrak etil asetat daun sukun dan menguji aktivitasnya sebagai antikanker. Daun sukun diekstraksi dengan etanol 70\% kemudian dilakukan partisi dengan petroleum eter dan etil asetat. Ekstrak etil asetat yang diperoleh difraksinasi dengan kromatografi kolom silica gel dengan gradient elusi heksanetil asetat sehingga diperoleh senyawa kristal berwarna kuning, AA3. Senyawa AA3 kemudian diidentifikasi dengan spektrofotometer UV-Vis, LC-MS, ${ }^{1} \mathrm{H}-\mathrm{NMR}$ dan ${ }^{13} \mathrm{C}-\mathrm{NMR}$ dan diperoleh hasil bahwa senyawa AA3 tersebut adalah siklokomunol yang merupakan golongan pyranoflavonoid. Uji antikanker siklokomunoldengan MCF-7 dan T47D menunjukkan adanya aktivitas antikanker dengan nilai $\mathrm{IC}_{50}$ masing-masing adalah $75.46 \mu \mathrm{M}$ dan $36.20 \mu \mathrm{M}$ selama 48 jam.

Kata kunci : Artocarpus altilis, siklokomunol, antikanker, MCF-7, T47D.

ABSTRACT

Leaves of breadfruit Artocarpus altilis (Parkinson) Fosberg has long been used as traditional medicine to overcome a variety of diseases such as liver cirrhosis, hypertension, and diabetes. Ethyl acetate extract of the leaves of breadfruit also potentially inhibit the growth of cancer cells. Several compounds have been known as an anticancer agent in the ethyl acetate extract of leaves of breadfruit is belong to geranyl flavonoid group. However, the compound belong to pyranoflavoid grouphas not been reported can be found on the leaves of breadfruit. Therefore, this study aims to
\end{abstract}

isolate the pyranoflavonoid compound from ethyl acetate extract of leaves of breadfruit and tested as an anticancer agent. Breadfruit leaves were extracted with $70 \%$ ethanol and then made $\square \square$ a partition with petroleum ether and ethyl acetate. Ethyl acetate extract obtained was fractionated by silica gel column chromatography with gradient elution of hexane-ethyl acetate to obtain a yellow crystalline compound, AA3. AA3 compound was identified by UV-Vis spectrophotometer, LC-MS, $1 H-N M R$ and $13 C-N M R$ and obtained results that $A A 3$ compound is siklokomunolwhich is belong to pyranoflavonoid group. Anticancer test of siklokomunolwith MCF-7 and T47D showed anticancer activity with IC50 values $\square$ of each are $75.46 \mu \mathrm{M}$ and 36.20 $\mu M$, respectively, for 48 hours.

Keywords : Artocarpus altilis, cyclocommunol, anticancer, MCF-7, T47D.

\section{PENDAHULUAN}

Tanaman sukun Artocarpus altilis (Parkinson) Fosberg termasuk ke dalam genus Artocarpus, dan famili Moraceae.Tanaman ini terdapat pada daerah tropis seperti di Asia Tenggara dan kepulauan pasifik.Di Indonesia, daun sukun sudah lama dijadikan sebagai obat tradisional untuk mengatasi berbagai penyakit seperti liver cirrhosis, hipertensi, dan diabetes ${ }^{(1)}$. Selain itu, penelitian yang dilakukan sebelumnya telah dilaporkan bahwa ekstrak dari daun sukun dapat berperan sebagai agen antiatherosklerosis ${ }^{(2)}$.

Wang et al. telah melaporkan bahwa ekstrak etil asetat dari daun sukun dapat memiliki khasiat sebagai antiatherosklerosis karena dapat melindungi sel lini U937 manusia dari perusakan yang disebabkan oleh OxLDL atau Oxidized Low Density Lipoprotein. Beberapa senyawa golongan flavonoid dan $\beta$-sitosterol dari ekstrak etil asetat daun sukun dilaporkan dapat menghambat perusakan sel lini U937 oleh OxLDL 
dengan mekanisme penangkapan radikal bebas yang disebabkan oleh adanya $\mathrm{OxLDL}{ }^{(2)}$.

Selain itu, Wang et al. juga telah melaporkan adanya potensi penghambatan pertumbuhan sel kanker dari ekstrak etil asetat dari sukun.Beberapa senyawa yang telah diketahui sebagai agen antikanker di dalam ekstrak etil asetat daun sukun adalah tergolong geranil flavonoid.Pada penelitiannya itu, senyawa-senyawa geranil flavonoid yang berhasil diisolasi dari ekstrak etil asetat daun sukun dapat menghambat pertumbuhan beberapa sel lini kanker manusia seperti sel adenokarsinoma paru-paru (SPC-A-1), sel karsinoma kolon (SW-480), dan sel karsinoma hati $(\mathrm{SMMC}-7721)^{(3)}$.

Lin dan Shieh telah mengisolasi 4 senyawa pyranoflavonoid pada kulit akar dari kerabat sukun yakni Artocarpus communis. Senyawa-senyawa tersebut antara lain adalah siklokomunol, cyclocommunin, dihydroisocycloartomunin, dan cyclomulberrin ${ }^{(4)}$. Golongan pyranoflavonoid telah dilaporkan sebelumnya memiliki aktivitas sebagai antikanker pada beberapa jenis sel lini kanker manusia ${ }^{(5)}$.Akan tetapi, senyawa pyranoflavoid belum dilaporkan dapat ditemukan pada sukun khususnya di bagian daun.Golongan flavonoid seperti disebutkan sebelumnya banyak ditemukan pada ekstrak etil asetat dari daun sukun ${ }^{(2,3)}$. Untuk itu, penelitian ini bertujuan untuk mengisolasi senyawa pyranoflavonoid dari ekstrak etil asetat daun sukun dan menguji aktivitasnya sebagai antikanker.

\section{BAHAN DAN METODA}

\section{Bahan}

Daun sukun (Artocarpus altilis) diperoleh di Bandung, Jawa Barat dan telah diidentifikasi oleh Laboratorium Biologi, Institut Teknologi Bandung.Pelarut organik kualitas teknik yang telah didestilasi (n-heksana, etil asetat, dan etanol).Silika gel dan petroleum eter dari E.Merck.Dulbecco's Modified Eagle's Medium (DMEM) dari Gibco.Fetal bovine serum (FBS) dari Sigma

\section{Peralatan}

LC-MS (Liquid Chromatography - Mass Spectrometer) Mariner Biospectrometry yang dilengkapi dengan sistem ESI (Electrospray Ionization) dan mode ion positif.Spektroskopi NMR $500 \mathrm{MHz}$ JEOL JNM ECA-500 spectrometer.Microplate reader Labsystem Multiskan MS.

\section{Ekstraksi, Isolasi, dan Identifikasi}

Daun sukun yang telah kering $(2.4 \mathrm{Kg}$ ) diekstrasi dengan etanol $70 \%$ menggunakan maserator selama 3
hari.Ekstrak etanol yang diperoleh kemudian dipekatkan dengan rotavapor sehingga diperoleh beratnya 200 gram.Ekstrak etanol kemudian dipartisi dengan petroleum eter-air (2:1) sebanyak 4 kali.Ekstrak air kemudian ditambahkan etil asetat untuk memperoleh ekstrak etil asetat. Ekstrak etil asetat kemudian dipekatkan dengan rotavaporsehingga diperoleh beratnya hingga 78 gram. Ekstrak etil asetat kemudian difraksinasi dengan kromatografi kolom silica gel dengan gradient elusi dengan eluen heksan-etil asetat (maksimal 8:2) sehingga diperoleh 61 fraksi. Fraksi 40 hingga 61 dikumpulkan ( $0.4 \mathrm{~g})$ dan difraksinasi kembali dengan gradient elusi heksan-etil asetat sehingga diperoleh senyawa kristal berwarna kuning, AA3. Kristal tersebut kemudian diidentifikasi dengan LCMS, ${ }^{1} \mathrm{H}-\mathrm{NMR}$, dan ${ }^{13} \mathrm{C}-\mathrm{NMR}$ spectrometer.

\section{Uji aktivitas antikanker dengan MTS}

Metode uji aktivitas antikanker mengikuti prosedur yang dilakukan oleh Meiyanto et al. ${ }^{(6)}$ dengan sedikit dimodifikasi.Sel lini kanker manusia T47D dan MCF-7 ditumbuhkan ke dalam sumur pada 96-well plate dengan jumlah $5 \times 10^{4}$ sel per sumur dan diinkubasi pada suhu $37^{\circ} \mathrm{C}$ selama 24 jam di dalam media pertumbuhan Dulbecco's Modified Eagle's Medium (DMEM, 10\% (v/v) fetal bovine serum (FBS), $100 \mathrm{U} / \mathrm{mL}$ penicillin, dan $100 \mu \mathrm{g} / \mathrm{mL}$ streptomycin). Sel kemudian diberi perlakuan dengan berbagai konsentrasi sampel dan doksorubisin sebagai kontrol positif selama 48 jam.Sel tanpa perlakuan juga diikusertakan sebagai kontrol negative.Setelah diinkubasi, ke dalam 96-well plateditambahkan reagen CellTiter $96 \circledast \mathrm{Aq}_{\text {ueous }}$ One Solution (Promega) ke dalam tiap sumur sesuai dengan instruksi manualnya. Setelah 4 jam, jumlah sel yang hidup diukur dengan alat microplate reader Labsystem Multiskan MS dengan panjang gelombang $490 \mathrm{~nm}$.

Perhitungan persentase viabilitas sel berdasarkan pada persamaan sebagai berikut:

$$
\text { Viabilitas sel (\%) }=\frac{\text { A sampel - A blanko }}{\text { A kontrol negatif - A blanko }} \times 100 \%
$$

\section{HASIL DAN PEMBAHASAN}

\section{${ }^{1} \mathrm{H}-\mathrm{NMR},{ }^{13} \mathrm{C}-\mathrm{NMR}$, dan LC-MS}

Data spektrum 1H-NMR dan 13C-NMR disajikan pada Tabel 1.Spektrum ${ }^{1} \mathrm{H}-\mathrm{NMR}$ dari senyawa AA3 mengindikasikan adanya 2 vinil metil pada $\delta 1.67$ (H-14) dan $1.94(\mathrm{H}-15)$ serta dua doublet $(J=10 \mathrm{~Hz})$ pada $\delta 5.4(\mathrm{H}-12)$ dan $6.13(\mathrm{C}-11)$. Sinyal proton aromatic tipe ABC terdeteksi pada $\delta 6.30(1 \mathrm{H}, d, 2.1 \mathrm{~Hz}$, $\left.\mathrm{H}^{\prime} 3^{\prime}\right), 6.52\left(1 \mathrm{H}, d d, 2.1 \mathrm{~Hz}, 8 \mathrm{~Hz}, \mathrm{H}-5^{\prime}\right)$, dan $7.61(1 \mathrm{H}, d$, $\left.8 \mathrm{~Hz}, \mathrm{H}-6^{\prime}\right)$.Doublet meta-couple $(J=2.5 \mathrm{~Hz})$ dapat ditemukan pada $\delta 6.39(\mathrm{H}-6)$ dan $6.16(\mathrm{H}-8)$, selain itu juga ditemukan gugus hidroksil terkelasi pada $\delta 12.87$. 
Tabel 1. Data spektrum ${ }^{1} \mathrm{H}-\mathrm{NMR}$ dan ${ }^{13} \mathrm{C}-\mathrm{NMR}$ dari senyawa AA3.

\begin{tabular}{|c|c|c|}
\hline & & Senyawa AA3 \\
\hline C & $\delta_{\mathrm{C}}(\mathrm{ppm})$ & $\begin{array}{l}\delta_{\mathrm{H}}(\mathrm{ppm})(\Sigma \mathrm{H}, \\
\text { multiplicity, } J)\end{array}$ \\
\hline 2 & 157.5 & \\
\hline 3 & 110.5 & \\
\hline 4 & 179.8 & \\
\hline 5 & 158.8 & \\
\hline 6 & 95.2 & $6.39(1 \mathrm{H}, d, 2.5 \mathrm{~Hz})$ \\
\hline 7 & 165.8 & \\
\hline 8 & 100.2 & $6.16(1 \mathrm{H}, d, 2.5 \mathrm{~Hz})$ \\
\hline 9 & 163.5 & \\
\hline 10 & 105.7 & \\
\hline 11 & 70.8 & $6.13(1 \mathrm{H}, d, 10 \mathrm{~Hz})$ \\
\hline 12 & 122.6 & $5.4(1 \mathrm{H}, d, 10 \mathrm{~Hz})$ \\
\hline 13 & 140.0 & \\
\hline 14 & 18.8 & $1.67(3 \mathrm{H}, \mathrm{s})$ \\
\hline 15 & 26.1 & $1.94(3 \mathrm{H}, \mathrm{s})$ \\
\hline $1^{\prime}$ & 111.2 & \\
\hline $2^{\prime}$ & 159.7 & \\
\hline $3^{\prime}$ & 105.2 & $6.30(1 \mathrm{H}, d, 2.1 \mathrm{~Hz})$ \\
\hline $4^{\prime}$ & 164.9 & \\
\hline $5^{\prime}$ & 112.2 & $6.52(1 \mathrm{H}, d d, 2.1 \mathrm{~Hz}, 8 \mathrm{~Hz})$ \\
\hline $6^{\prime}$ & 126.5 & $7.61(1 \mathrm{H}, d, 8 \mathrm{~Hz})$ \\
\hline $5-\mathrm{OH}$ & & $12.87(1 \mathrm{H}, \mathrm{s})$ \\
\hline
\end{tabular}

Hasil analisa senyawa AA3 dengan LC-MS menunjukkan bahwa m/e adalah 352.96, sehingga dari nilai tersebut maka dapat diketahui bahwa massa sesungguhnya adalah 351.96. Dari hasil analisa spektrum ${ }^{1} \mathrm{H}-\mathrm{NMR},{ }^{13} \mathrm{C}-\mathrm{NMR}$, LC-MS, dan dibandingkan dengan data siklokomunol yang diperoleh oleh $\mathrm{Lin}$ dan $\mathrm{Shieh}^{(4)}$ maka dapat ditentukan bahwa senyawa AA3 tersebut adalah suatu senyawa golongan pyranolflavonoid yakni siklokomunol atau 3,8,10-Trihydroxy-6-(2-methyl-1-propenyl)-6H, 7H[1]benzopyrano[4,3-b] [1] benzopyran-7-one (Gambar 1).

Seperti dilaporkan sebelumnya bahwa Lin dan Shieh $^{(4)}$ telah mengisolasi siklokomunol dari kulit akar tanaman kerabat sukun yakni Artocarpus communis, hanya saja banyaknya siklokomunol yang dapat diisolasi tidak dilaporkan jumlahnya.Hasil penilitian ini menunjukkan bahwa ternyata pada daun sukun (Artocarpus altilis) juga terdapat senyawa siklokomunol.Rendemen senyawa siklokomunol ini adalah sebesar $0.017 \%$ dari ekstrak daun sukun kering (Artocarpus altilis).

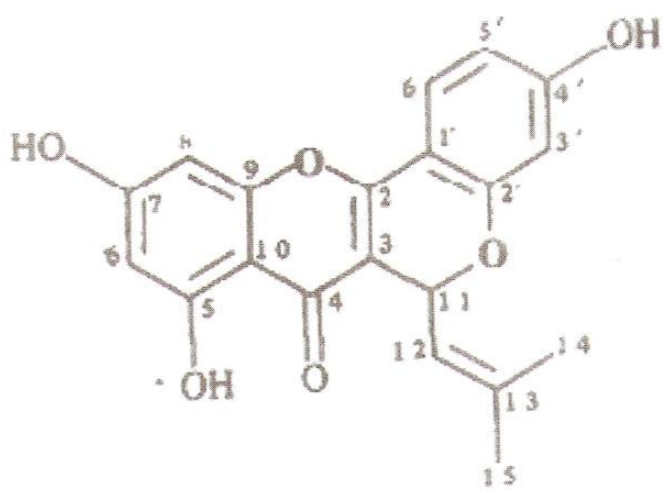

Gambar 1. Senyawa cyclocommunol

\section{Aktivitas Antikanker}

Aktivitas antikanker dari doksorubisin terhadap 2 tipe sel kanker payudara manusia yakni T47D dan MCF-7 memiliki daya hambat yang berbeda yang sangat signifikan (Gambar 2).Nilai $\mathrm{IC}_{50}$ doksorubisin terhadap sel MCF-7 hampir lima belas kali lipat lebih tinggi daripada nilai $\mathrm{IC}_{50}$ doksorubisin terhadap sel T47D, dengan inkubasi selama 48 jam. Hasil ini menyatakan bahwa sel MCF-7 lebih sulit dihambat proliferasinya oleh doksorubisindaripada sel T47D.Fitriasari et al. ${ }^{(7)}$ telah melaporkan bahwa nilai $\mathrm{IC}_{50}$ doksorubisin terhadap sel MCF-7 adalah sebesar $467 \mathrm{nM}$ atau setara dengan $0.467 \mu \mathrm{M}$, dengan inkubasi selama 24 jam. Begitu juga dengan nilai $\mathrm{IC}_{50}$ doksorubisin terhadap sel T47D, telah dilaporkan oleh Junedi et $a l^{(8)}$, adalah sebesar $15 \mathrm{nM}$ atau setara dengan $0.015 \mu \mathrm{M}$, dengan inkubasi selama 24 jam. Sehingga dengan demikian, terdapat kecenderungan yang sama dengan penelitian ini yaitu nilai $\mathrm{IC}_{50}$ pada $\mathrm{MCF}-7$ lebih besar dari nilai $\mathrm{IC}_{50}$ pada T47D.

Besarnya nilai $\mathrm{IC}_{50}$ doxorubicin pada $\mathrm{MCF}-7$ menandakan bahwa sel $\mathrm{MCF}-7$ resisten terhadap doxorubicin. Resistensi ini dapat disebabkan karena tingginya jumlah Bcl-2 dan P-gp pada sel MCF-7 tersebut ${ }^{(9)}$. Bcl-2 merupakan golongan protein antiapoptosis yang berperan terhadap penghambatan apoptosis atau kematian sel secara terprogram, sedangkan P-gp merupakan salah satu dari protein multidrug resistance (MDR) yang terdapat pada membran sel, dan bertanggung jawab terhadap penolakan senyawa obat yang akan masuk ke dalam sel ${ }^{(10)}$. Dengan demikian, Bcl-2 dan P-gp dapat bekerja secara simultan dalam mencegah kematian sel kanker. 


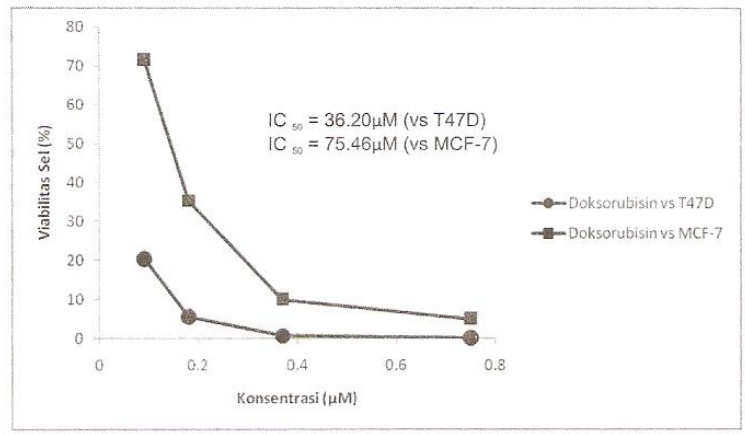

Gambar 2. Aktivitas antikanker doksorubisin terhadap sel T47D dan MCF-7 selama 48 jam.

Aktivitas antikanker dari siklokomunol terhadap 2 tipe sel kanker payudara manusia yakni T47D dan MCF-7 memiliki daya hambat yang berbeda yang cukup signifikan (Gambar 3).Nilai $\mathrm{IC}_{50}$ siklokomunol terhadap sel MCF-7 sekitar 2 kali lebih tinggi daripada nilai $\mathrm{IC}_{50}$ siklokomunol terhadap sel $\mathrm{T} 47 \mathrm{D}$, dengan inkubasi selama 48 jam.Hasil ini menyatakan bahwa sel MCF-7 lebih sulit dihambat proliferasinya oleh siklokomunol daripada sel T47D.Selain itu, nilai $\mathrm{IC}_{50}$ siklokomunol pada kedua tipe sel kanker tersebut jauh lebih besar daripada nilai $\mathrm{IC}_{50}$ doksorubisin terhadap sel MCF-7 dan T47D.Akan tetapi, senyawa siklokomunol tetap memiliki aktivitas sebagai antikanker walaupun tergolong tidak terlalu kuat.

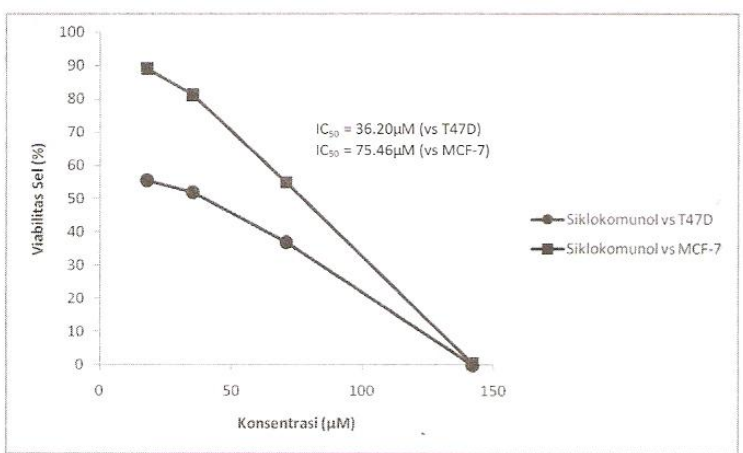

Gambar 3. Aktivitas antikanker siklokomunol terhadap sel T47D dan MCF-7 selama 48 jam.

Aktivitas antikanker golongan pyranoflavonoid lainnya seperti dilaporkan oleh Peng et al. ${ }^{(11)}$, telah diketahui bahwa senyawa (2S)-5,2',6'-trihydroxy$2^{\prime \prime}, 2^{\prime \prime}$-dimethylpyrano[5",6":6,7] flavanone dan (2S, $\left.3^{\prime \prime S}\right)-5,2^{\prime}, 6^{\prime}$-trihydroxy-3" -y,y-dimathylallyl-2" , 2"dimethyl-3",4"- dihydropyrano[5",6":6,7] flavanone memiliki aktivitas antikanker terhadap sel MCF-7 dengan $\mathrm{IC}_{50}$ masing-masing adalah $35.48 \mu \mathrm{g} / \mathrm{ml}$ $(100.23 \mu \mathrm{M})$ dan $18.53 \mu \mathrm{g} / \mathrm{ml}(43.81 \mu \mathrm{M})$. Penelitian yang dilakukan oleh Peng et al. ${ }^{(11)}$ menyatakan bahwa senyawa flavanone tanpa gugus pyran yang diisolasi dari daun Patrinia villosadapat memiliki aktivitas antikanker yang lebih tinggi $\left(\mathrm{IC}_{50}<20 \mu \mathrm{M}\right)$ daripada senyawa flavanone yang memiliki gugus pyran.

\section{KESIMPULAN}

Hasil penilitian ini menunjukkan bahwa ternyata pada daun sukun (Artocarpus altilis) juga terdapat senyawa siklokomunol seperti yang ditemukan pada kulit akar dari tanaman kerabatnya (Artocarpus communis).Rendemen senyawa siklokomunol ini adalah sebesar $0.017 \%$ dari ekstrak daun sukun kering (Artocarpus altilis). Nilai $\mathrm{IC}_{50}$ siklokomunolterhadap sel MCF-7 adalah $75.46 \mu \mathrm{M}$ dan nilai $\mathrm{IC}_{50}$ siklokomunol terhadap sel T47D adalah $36.20 \mu \mathrm{M}$ dengan inkubasi selama 48 jam.

\section{UCAPAN TERIMA KASIH}

Penulis mengucapkan terima kasih kepada Pusat Penelitian Kimia LIPI. Penelitian ini menggunakan dana dari DIPA Tematik LIPI tahun 2011-2012.Penulis juga berterima kasih kepada Prof. Dr. Muhammad Hanafi dari Pusat Penelitian Kimia LIPI yang telah memberikan arahan dalam elusidasi struktur senyawa dan Ibu Uun Sundawati yang telah membantu dalam isolasi senyawa siklokomunol.

\section{DAFTAR PUSTAKA}

1. S. Kasahara, S. Hemmi. Medicinal Herb Index in Indonesia. PT Eisai Indonesia, Bogor, 1988.

2. Y. Wang, T. Deng, L. Lin, Y. Pan, X. Zheng. 2006. Bioassay-guided isolation of antiatherosclerotic phytochemicals from Artocarpus altilis. Phytother. Res.20: 1052-1055 (2006).

3. Y. Wang, K. Xu, L. Lin, Y. Pan, X. Zheng. Geranyl flavonoids from the leaves of Artocarpus altilis. Phytochem. 68: 1300-1306(2007).

4. C.N. Lin, W.L. Shieh. Pyranoflavonoids from Artocarpus communis. Phytochemistry. 31 (8): 2922-2924 (1992).

5. J. Peng, G. Fan, Y. Wu. Preparative isolation of four new and two known flavonoids from the leaf of Patrinia villosa Juss. By counter-current chromatography and evaluation of their anticancer activities in vitro. J. Chrom. A.1115: 103-111 (2006).

6. E. Meiyanto, A. Fitriasari, A. Hermawan, S. Junedi, R.A. Susidarti. The improvement of doxorubicin activity on breast cancer cell lines by tangeretin through cell cycle modulation. Orient. Pharm. Exp. Med.11(3): 183-190 (2011). 
7. A. Fitriasari, R.A. Susidarti, E. Meiyanto. Peningkatan efek sitotoksik doxorubicin oleh naringenin melalui pemacuan apoptosis sel kanker payudara MCF-7. Jurnal Bahan Alam Indonesia. 7(3): 165-170 (2010).

8. S. Junedi, R.A. Susidarti, E. Meiyanto. Peningkatan efek sitotoksik doxorubicin oleh naringenin pada sel kanker payudara T47D melalui induksi apoptosis. Jurnal Ilmu Kefarmasian Indonesia. 8: 85-90 (2010).

9. J.M. Davis, P.M. Navolanic, C.R. WeinsteinOppenheimer, L.S. Steelman, W. Hu, M. Konopleva, M.V. Blagosklonny, J.A. McCubrey. Raf-1 and Bcl-2 induce distinct and common pathways that contribute to breast cancer drug resistance. Clin. Cancer. Res. 9: 1161-1170 (2003).

10. K. Ueda, D.P. Clark, C.J. Chen, I.B. Roninson, M.M. Gottesman, I. Pastan. The human multidrug resistance (mdr1) gene. cDNA cloning and transcription initiation. J. Biol. Chem. 262(2):505508 (1987).

11. J. Peng, G. Fan, Y. Wu. Preparative isolation of four new and two known flavonoids from the leaf of Patrinia villosa Juss. by counter-current chromatography and evaluation of their anticancer activities in vitro. J. Chrom. A. 1115: 103-111 (2006). 